\title{
Pengaruh Kepemimpinan Transformasional dan Budaya Organisasi Terhadap Motivasi Serta Dampaknya Terhadap Kinerja Pegawai Pengadilan Negeri Jambi
}

\author{
Firman Syah Noor \\ Universitas Islam Negeri Sulthan Thaha Saifuddin Jambi \\ Correspondence email: firmansyahnoor@uinjambi.ac.id
}

\begin{abstract}
Abstrak. Penelitian ini bertujuan untuk mengetahui dan menganalisis gambaran kepemimpinan transformasional, budaya organisasi, motivasi dan kinerja, serta hubungan diantara keempat variabel tersebut pada pegawai Pengadilan Negeri Jambi Penelitian ini menggunakan metode penelitian deskriptif dan verifikatif yang bertujuan untuk mendeskripsikan variabel penelitian secara sistematis dan sesuai dengan fakta yang diselidiki, serta mengetahui hubungan antar variabel melalui pengujian hipotesis. Sampel penelitian yang digunakan sebanyak 74 orang pegawai Pengadilan Negeri Jambi, Hasil analisis deskriptif menunjukkan bahwa secara keseluruhan tingkat kualitas kepemimpinan transformasional dan budaya organisasi di Pengadilan Negeri Jambi berada pada tingkat kualitas yang baik. Sementara untuk motivasi kerja dan kinerja pegawai berada pada tingkat kualitas yang tinggi. Hasil pengujian hipotesis melalui analisis jalur membuktikan bahwa kepemimpinan transformasional dan budaya organisasi baik secara parsial maupun simultan berpengaruh signifikan terhadap kinerja pegawai. Untuk pengaruh tidak langsung dari kepemimpinan transformasional dan budaya organisasi terhadap kinerja pegawai melalui motivasi kerja, menunjukkan bahwa penerapan kepemimpinan transformasional dan budaya organisasi yang baik dapat meningkat motivasi kerja pegawai pada tingkat yang lebih tinggi, yang secara tidak langsung juga berdampak pada peningkatan kinerja pegawai. Namun, di sisi lain motivasi kerja secara parsial tidak berpengaruh terhadap kinerja pegawai.
\end{abstract}

Kata Kunci: Kepemimpinan transformasional, Budaya, Motivasi dan Kinerja.

\begin{abstract}
This study aims to determine and analyze the description of transformational leadership, organizational culture, motivation and performance, and the relationship between the four variables at the Jambi District Court employees. This study uses descriptive and verificative research methods that aim to describe research variables systematically and in accordance with the facts investigated, as well as knowing the relationship between variables through testing hypotheses. The study sample used as many as 74 employees of the Jambi District Court, The results of the descriptive analysis show that the overall level of transformational leadership quality and organizational culture in the Jambi District Court are at a good level of quality. While for work motivation and employee performance are at a high level of quality. The results of hypothesis testing through path analysis prove that transformational leadership and organizational culture both partially and simultaneously have a significant effect on work motivation and employee performance. For the indirect effects of transformational leadership and organizational culture on employee performance through work motivation, it shows that the application of transformational leadership and good organizational culture can increase employee motivation at a higher level, which indirectly has an impact on improving employee performance. However, on the other hand work motivation partially does not affect employee performance.
\end{abstract}

Keyword: Transformational leadership, organizational culture, and motivation

\section{PENDAHULUAN}

Sumber daya manusia merupakan aset yang sangat penting dari sebuah organisasi, termasuk lembaga penegak hukum. Oleh karenanya, keberhasilan suatu penegakan hukum sangat ditentukan oleh kualitas sumber daya manusia yang ada didalamnya, mulai dari kemampuan menangkap perubahan lingkungan, melakukan analisa serta mengantisipasi dampaknya terhadap instansi tersebut. Pegawai yang bekerja sesuai dengan fungsinya akan menunjang tercapainya keberhasilan tujuan organisasi. Lembaga peradilan adalah alat perlengkapan negara yang bertugas mempertahankan tetap tegaknya hukum nasional.

Hukum diciptakan untuk mewujudkan kehidupan masyarakat yang damai dan tenteram. Agar hukum dapat berjalan efektif maka perlu diadakan penegakan hukum. Penegakan hukum di sini juga termasuk pemberian hukuman atau sanksi (pidana ataupun perdata) bagi pelanggar hukum. Untuk itu, dibutuhkan lembaga penegak hukum dan pejabat hukum. Pengadilan Negeri Jambi merupakan kawal depan Mahkamah Agung Republik Indonesia dalam memberikan pelayanan bagi pencari keadilan. Berdasarkan Undang - undang Nomor 49 tahun 2009 tentang Peradilan Umum. Tugas pokok dan fungsi Pengadilan negeri Jambi yang bertugas dan berwenang memeriksa, mengadili dan memutus perkara perdata, pidana, tipikor dan hubungan industrial. Manajemen SDM sangat berperan penting untuk mengatur pengelolaan SDM dan sumberdaya agar memberikan hasil maksimal dan memiliki loyalitas tinggi. Selain itu juga akan memiliki profesionalitas terbaik yang dapat diandalkan untuk mencapai tujuan dan sasaran yang telah ditetapkan. Profesionalitas itu sendiri dapat diukur dari kinerja SDM yang ada di dalam kantor. Hasil kinerja para pegawai negeri sipil di lingkungan pengadilan negeri jambi 
Firman Syah Noor, Pengaruh Kepemimpinan Transformasional dan Budaya Organisasi Terhadap Motivasi Serta Dampaknya Terhadap Kinerja Pegawai Pengadilan Negeri Jambi

Tabel 1. Perkembangan Program Kegiatan Pengadilan Negeri Jambi

\begin{tabular}{lccccc}
\hline & \multicolumn{5}{c}{ Rasio Capaian (\%) } \\
\hline \multicolumn{1}{c}{ Jenis Perkara } & $\mathbf{2 0 1 5}$ & $\mathbf{2 0 1 6}$ & $\mathbf{2 0 1 7}$ & $\mathbf{2 0 1 8}$ & $\mathbf{2 0 1 9}$ \\
Perkara Perdata & 87,25 & 88,46 & 88,33 & 86,23 & 72,28 \\
Perkara Pidana & 83,23 & 82,33 & 80,14 & 87,26 & 84,55 \\
Perkara Tipikor & 68,14 & 67,27 & 61,54 & 71,83 & 80 \\
Perkara PHI & 91,14 & 94,44 & 75,00 & 79,31 & 85,18 \\
Jumlah & $\mathbf{8 2 , 4 4}$ & $\mathbf{8 3 , 1 3}$ & $\mathbf{7 6 , 2 5}$ & $\mathbf{8 1 , 1 6}$ & $\mathbf{8 0 , 5 0}$ \\
\hline
\end{tabular}

Sumber: Pengadilan Negeri jambi, 2020

Terlihat dari tabel perkembangan program kegiatan pengadilan negeri Jambi tahun 2020 bahwa kinerja penyelesaian jenis perkara yang telah ada belum ada yang tercapai $100 \%$ dari jumlah jenis perkara yang ada di tahun 2019. Dari keempat jenis perkara yang ditangani Pengadilan Negeri Jambi, diketahui bahwa perkara PHI memiliki rata-rata tingkat ketercapaian tertinggi dibandingan 3 jenis perkara lainnya, yaitu sebesar 85\% sepanjang tahun 2015-2019. Kinerja pegawai di sektor publik juga dipengaruhi oleh Budaya organisasi, karena berpengaruh dalam menciptakan pelayanan publik yang baik. Salah satu budaya organisasi yakni kompetensi secara pribadi dari pegawai. Dengan adanya interaksi atau komunikasi antar pegawai maupun interaksi komunikasi antara pegawai dengan publik, maka akan memupuk budaya organisasi yang baik. Budaya organisasi merupakan suatu sistem nilai, kepercayaan dan kebiasaan dalam suatu organisasi yang menjadi norma-norma perilaku organisasi (Hadian,Adang, 2014). Faktor lain yang mempengaruhi kinerja selain kepemimpinan adalah motivasi, hal tersebut erat kaitannya dengan kinerja seperti yang pernah di ulas oleh (Sedarmayanti, 2010) bahwa kepemimpinan tranformasional lebih meningkatkan motivasi dan kinerja pengikutnya, sehingga erat kaitannya dengan motivasi sebagai peningkatan kinerja. Menjadi tantangan bagi pemimpin apakah kebijakankebijakan nya tersebut mampu memotivasi atau meningkatkan produktifitas, jika tidak malah bisa menimbulkan stress kerja dan berakibat pada kendurnya motivasi pribadi, dan malah menurunkan loyalitas karyawan. Adapun tujuan yang hendak dicapai dalam penelitian ini adalah (1) Mengetahui dan menganalisis gambaran kondisi kepemimpinan transformasional, budaya organisasi, motivasi dan kinerja pegawai Pengadilan Negeri Jambi. (2) Mengetahui dan menganalisis pengaruh kepemimpinan transformasional terhadap motivasi kerja pegawai Pengadilan Negeri Jambi secara parsial. (3) Mengetahui dan menganalisis pengaruh motivasi kerja terhadap kinerja pegawai Pengadilan Negeri Jambi secara parsial. (4) Mengetahui dan menganalisis pengaruh kepemimpinan transformasional dan budaya organisasi terhadap kinerja pegawai Pengadilan Negeri Jambi melalui motivasi kerja.

\section{Kepemimpinan Transformasional}

Menurut (Robbins, Judge, 2008) kepemimpinan transformasional adalah kemampuan seorang pemimpin menginspirasi para pengikutnya untuk mengenyampingkan kepentingan pribadi mereka demi kebaikan organisasi dan mereka mampu memiliki pengaruh yang luar biasa pada diri pengikutnya. Menurut (Tjiptono, 2006) gaya kepemimpinan adalah suatu cara yang digunakan pemimpin dalam berinteraksi dengan bawahannya. Gaya pemimpin transformasional mencurahkan perhatian pada hal-hal dan kebutuhan pengembangan masing-masing pengikut dan gaya kepemimpinan yang dianggap mampu meningkatkan kinerja karyawan adalah gaya kepemimpinan transformasional.

\section{Budaya Organisasi}

Budaya Organisasi mengacu pada sistim berbagai arti yang dilakukan oleh para anggota organisasi yang membedakan organisasi tersebut dengan organisasi lain (Soedjono, 2005), mengatakan bahwa budaya organisasi adalah suatu sistem penyebaran kepercayaan dan nilai nilai yang berkembang dalam suatu organisasi dan mengarahkan perilaku anggota-anggotanya.

\section{Motivasi}

Dalam kehidupan berorganisasi, pemberian dorongan sebagai bentuk motivasi kerja kepada bawahan penting dilakukan untuk meningkatkan kinerja karyawan. Menurut (Malayu,2007), motivasi berasal dari kata latin movere yang berarti dorongan atau pemberian daya penggerak yang menciptakan kegairahan kerja seseorang agar mereka mau bekerja sama, bekerja efektif, dan terintegrasi dengan segala daya upaya nya untuk mencapai kepuasan. Motivasi merupakan faktor yang kehadirannya dapat menimbulkan kepuasan kerja, dan meningkatkan kinerja karyawan. Kemudian (Siagian, 2011) mengatakan bahwa dalam kehidupan berorganisasi, termasuk kehidupan berkarya dalam organisasi, aspek motivasi kerja mutlak mendapat perhatian serius dari para pemimpin yang setiap hari berkontak langsung dengan bawahan di tempat kerja. Motivasi sendiri adalah reaksi yang timbul dari dalam diri seseorang sebagai dorongan karena adanya rangsangan dari luar yang mempengaruhi untuk memenuhi tujuan tertentu (Suranta, 2005) 


\section{Kinerja Pegawai}

Kinerja dalam bahasa Inggris disebut dengan performance, yang juga memiliki arti prestasi. Dalam organisasi, kinerja dapat diartikan sebagai pencapaian tujuan yang telah ditetapkan dalam organisasi. Kinerja merupakan suatu fungsi dari motivasi dan kemampuan. Untuk menyelesaikan tugas/pekerjaan, seseorang harus memiliki derajat kesediaan dan tingkat kemampuan. Kinerja juga dinyatakan sebagai kualitas dan kuantitas dari pencapaian tugas - tugas, baik yang dilakukan oleh individu, kelompok maupun perusahaan.

\section{METODE}

\section{Jenis Data dan Sumber Data}

Jenis data yang diperoleh yaitu Data primer yaitu Pada penelitian ini data primer diperoleh dari hasil pengisian kuesioner mengenai tanggapan pegawai berkenaan dengan kepemimpinan transformasional dan budaya organisasi terhadap motivasi dan dampaknya terhadap Kinerja Pegawai Pengadilan Negeri Jambi dan Data sekunder adalah data yang diperoleh dalam bentuk sudah jadi dan sudah dipublikasikan.

\section{Populasi dan Sampel}

Populasi dalam penelitian ini adalah Pegawai Pengadilan Negeri Jambi sebanyak 74 orang. Sampel penelitian adalah sebagian dari populasi yang diambil sebagai sumber data dan dapat mewakili seluruh populasi.

Metode penentuan sampel yang digunakan dalam penelitian ini adalah metode sampel jenuh. Metode sampel jenuh adalah teknik penentuan sampel bila semua anggota populasi digunakan menjadi sampel.

\section{Uji hipotesis}

\section{Uji F (Simultan)}

Uji ini dimaksudkan untuk mengetahui signifikan pengaruh variabel independent terhadap variabel dependen secara bersama-sama, yaitu apakah kepemimpinan transformasional $\left(\mathrm{X}_{1}\right)$ dan budaya organisasi $\left(\mathrm{X}_{2}\right)$ secara bersama-sama berpengaruh terhadap motivasi kerja (Y) dan kinerja (Z).

Keputusan yang diambil berdasarkan perbandingan antara nilai signifikansi yang didapatkan dengan derajat tingkat kepercayaan $(\alpha)$ yaitu 0,05 .

a. Jika nilai signifikansi yang didapatkan lebih kecil dari 0,05 (sig. < 0,05), maka kepemimpinan transformasional $\left(\mathrm{X}_{1}\right)$ dan budaya organisasi $\left(\mathrm{X}_{2}\right)$, secara bersama-sama berpengaruh signifikan terhadap motivasi kerja (Y) dan atau kinerja (Z).

b. Jika nilai signifikansi yang didapatkan lebih besar dari 0,05 (sig

c. >0,05), maka kepemimpinan transformasional $\left(X_{1}\right)$ dan budaya organisasi $\left(\mathrm{X}_{2}\right)$, secara bersama-sama berpengaruh tidak signifikan terhadap motivasi kerja (Y) dan atau kinerja (Z).

\section{Uji t (Parsial)}

Uji parsial (uji t) digunakan untuk menjawab hipotesis satu, dua, empat, lima, dan tujuh. Pedoman dalam pengujian ini berdasarkan pada perbandingan nilai $t_{\text {hitung }}$ dengan nilai $t_{\text {tabel }}$ pada derajat kesalahan $5 \%$. Apabila nilai $t_{\text {hitung }}>\mathrm{t}_{\text {tabel }}$, maka variabel bebas (X) memberi pengaruh yang signifikan terhadap variabel terikat (Y). Sebaliknya apabila nilai $\mathrm{t}_{\text {hitung }}<\mathrm{t}_{\text {tabel }}$, maka variabel bebas $(\mathrm{X})$ memberi pengaruh yang tidak signifikan terhadap variabel terikat (Y). berikut:

Adapun keputusan pengujian hipotesis sebagai

$\mathrm{H}_{0}: \beta=0$ Artinya tidak terdapat pengaruh yang signifikan antara variabel $\mathrm{X}_{\mathrm{i}}$ terhadap variabel $\mathrm{Y}$

$\mathrm{H}_{\mathrm{a}}: \beta \neq 0$ Artinya terdapat pengaruh yang signifikan antara variabel $\mathrm{X}_{\mathrm{i}}$ terhadap variabel $\mathrm{Y}$

\section{Koefisien Determinasi $\left(\mathbf{R}^{2}\right)$}

Uji ini dilakukan untuk mengetahui seberapa besar kontribusi nilai variabel independen yaitu kepemimpinan transformasional dan budaya organisasi (X) serta motivasi kerja (Y) terhadap variabel dependen yaitu kinerja (Z). Adapun kontribusi nilai dari variabel independen (X) umumnya dinyatakan dalam bentuk " $\mathrm{R}^{2}$ ", yang merupakan kuadran dari nilai koefisien korelasi $\left(\mathrm{r}_{\mathrm{xy}}\right)$. Rumus yang digunakan dalam uji koefisien determinasi adalah sebagai berikut(Syekh, 2011):

$\mathrm{KD}\left(\mathrm{R}^{2}\right)=\mathrm{r}^{2} \times 100 \%$

keterangan:

$\mathrm{R}^{2}=$ nilai koefisien determinasi

$\mathrm{r}^{2}=$ nilai koefisien korelasi

\section{Intervening}

Pengujian hipotesis mediasi dapat dilakukan dengan prosedur yang dikembangkan oleh Sobel dan dikenal dengan uji Sobel (Sobel test). untuk menguji signifikansi pengaruh tidak langsung, maka kita perlu menghitung nilai $\mathrm{t}$ dari koefisien $\mathrm{ab}$. Adapun kriteria pengujian hipotesisnya sebagai berikut:

1. Apabila nilai $t_{\text {hitung }}>t_{\text {tabel}}$, maka $H_{1}$ diterima dan $H_{0}$ ditolak. Artinya terjadi pengaruh mediasi.

2. Apabila $t_{\text {hitung }}<t_{\text {tabel, }}$ maka $\mathrm{H}_{0}$ diterima dan $\mathrm{H}_{1}$ ditolak. Artinya tidak terjadi pengaruh mediasi.

\section{HASIL DAN PEMBAHASAN}

Pengujian validitas dan reliabilitas kuesioner dilakukan dengan menggunakan bantuan program analisis statistik SPSS 21. Perhitungan tersebut menghasilkan suatu koefisien korelasi $\left(\mathrm{R}_{\mathrm{xy}}\right)$ yang digunakan untuk mengukur tingkat validitas suatu item dan menentukan suatu item layak digunakan atau tidak. Untuk melihat validitas kuesioner pada program SPSS 21 adalah dengan melihat nilai corrected item-total correlation $\left(\mathrm{R}_{\mathrm{hitung}}\right.$ ), sedangkan untuk reliabilitas dengan melihat nilai croncbach's alpha if item deleted $\left(\mathrm{R}_{\text {hitung }}\right)$. 
Pedoman dalam menentukan validitas dan reliabilitas item kuesioner adalah dengan membandingkan nilai $R_{\text {hitung }}$ dengan nilai $R_{\text {tabel }}(0,235)$ pada $\mathrm{n}=74$ dan $\alpha=0,05$. Jika nilai $\mathrm{R}_{\text {hitung }}>$ nilai $\mathrm{R}_{\text {tabel }}$ $(0,235)$, maka item ke-i pada kuesioner tersebut sudah valid, namun jika nilai $R_{\text {hitung }}<$ nilai $R_{\text {tabel }}(0,235)$, maka item ke-i pada kuesioner tersebut tidak valid. Adapun hasil uji validitas dan reliabilitas kuesioner melalui program SPSS 21 adalah dengan melihat tabel 2 sebagai berikut:

Tabel 2. Nilai Validitas Dan Reliabilitas Kuesioner Kepemimpinan Transformasional

\begin{tabular}{ccccccccc}
\hline \multirow{2}{*}{$\begin{array}{c}\text { No. } \\
\text { Item }\end{array}$} & \multicolumn{3}{c}{ Validitas } & & \multicolumn{3}{c}{ Reliabilitas } \\
\cline { 2 - 8 } & $\mathbf{R}_{\text {hitung }}$ & $\mathbf{R}_{\text {tabel }}$ & Keterangan & Tingkat validitas & $\mathbf{R}_{\text {hitung }}$ & $\mathbf{R}_{\text {tabel }}$ & Keterangan & Tingkat reliabilitas \\
\hline 1 & 0,681 & 0,235 & Valid & Tinggi & 0,872 & 0,235 & Reliabel & Sangat Tinggi \\
3 & 0,695 & 0,235 & Valid & Tinggi & 0,870 & 0,235 & Reliabel & Sangat Tinggi \\
3 & 0,665 & 0,235 & Valid & Tinggi & 0,873 & 0,235 & Reliabel & Sangat Tinggi \\
4 & 0,692 & 0,235 & Valid & Tinggi & 0,871 & 0,235 & Reliabel & Sangat Tinggi \\
5 & 0,582 & 0,235 & Valid & Sedang & 0,881 & 0,235 & Reliabel & Sangat Tinggi \\
6 & 0,652 & 0,235 & Valid & Tinggi & 0,874 & 0,235 & Reliabel & Sangat Tinggi \\
7 & 0,581 & 0,235 & Valid & Sedang & 0,881 & 0,235 & Reliabel & Sangat Tinggi \\
8 & 0,645 & 0,235 & Valid & Tinggi & 0,874 & 0,235 & Reliabel & Sangat Tinggi \\
9 & 0,620 & 0,235 & Valid & Tinggi & 0,878 & 0,235 & Reliabel & Sangat Tinggi \\
10 & 0,510 & 0,235 & Valid & Sedang & 0,883 & 0,235 & Reliabel & Sangat Tinggi \\
\hline
\end{tabular}

Sumber: Data primer yang diolah, 2020

Berdasarkan hasil perhitungan dengan menggunakan analisis statistik SPSS 21 diperoleh bahwa setiap item kuesioner dinyatakan valid. Untuk aspek reliabilitas item diperoleh bahwa semua item pernyataan pada kuesioner sudah reliabel, dengan kriteria tingkat reliabilitas item sangat tinggi. Adapun kriteria tingkat validitas item kuesioner kepemimpinan transformasional didapatkan bahwa sebagian besar item kuesioner memiliki tingkat validitas-tinggi.

Tabel 3. Nilai Validitas Dan Reliabilitas Kuesioner Budaya Organisasi

\begin{tabular}{|c|c|c|c|c|c|c|c|c|}
\hline \multirow{2}{*}{$\begin{array}{c}\text { No.It } \\
\text { em }\end{array}$} & \multicolumn{4}{|c|}{ Validitas } & \multicolumn{4}{|c|}{ Reliabilitas } \\
\hline & $\mathbf{R}_{\text {hitung }}$ & $\mathbf{R}_{\text {tabel }}$ & Keterangan & Tingkat validitas & $\mathbf{R}_{\text {hitung }}$ & $\mathbf{R}_{\text {tabel }}$ & Keterangan & Tingkat reliabilitas \\
\hline 1 & 0,564 & 0,235 & Valid & Sedang & 0,897 & 0,235 & Reliabel & Sangat Tinggi \\
\hline 2 & 0,609 & 0,235 & Valid & Tinggi & 0,895 & 0,235 & Reliabel & Sangat Tinggi \\
\hline 3 & 0,686 & 0,235 & Valid & Tinggi & 0,892 & 0,235 & Reliabel & Sangat Tinggi \\
\hline 4 & 0,707 & 0,235 & Valid & Tinggi & 0,890 & 0,235 & Reliabel & Sangat Tinggi \\
\hline 5 & 0,760 & 0,235 & Valid & Tinggi & 0,885 & 0,235 & Reliabel & Sangat Tinggi \\
\hline 6 & 0,793 & 0,235 & Valid & Tinggi & 0,884 & 0,235 & Reliabel & Sangat Tinggi \\
\hline 7 & 0,528 & 0,235 & Valid & Sedang & 0,901 & 0,235 & Reliabel & Sangat Tinggi \\
\hline 8 & 0,842 & 0,235 & Valid & Sangat Tinggi & 0,881 & 0,235 & Reliabel & Sangat Tinggi \\
\hline 9 & 0,683 & 0,235 & Valid & Tinggi & 0,891 & 0,235 & Reliabel & Sangat Tinggi \\
\hline 10 & 0,437 & 0,235 & Valid & Sedang & 0,903 & 0,235 & Reliabel & Sangat Tinggi \\
\hline 11 & 0,496 & 0,235 & Valid & Sedang & 0,901 & 0,235 & Reliabel & Sangat Tinggi \\
\hline
\end{tabular}

Sumber: Data primer yang diolah, 2020

Berdasarkan hasil perhitungan dengan menggunakan analisis statistik SPSS 21 diperoleh bahwa setiap item kuesioner budaya organisasi dinyatakan valid. Untuk aspek reliabilitas item diperoleh bahwa semua item pernyataan pada kuesioner sudah reliabel, dengan kriteria tingkat reliabilitas item sangat tinggi. Adapun kriteria tingkat validitas item kuesioner budaya organisasi didapatkan bahwa sebagian besar item kuesioner memiliki tingkat validitas tinggi.

Tabel 4. Nilai Validitas Dan Reliabilitas Kuesioner Motivasi Kerja

\begin{tabular}{ccccccccc}
\hline \multirow{2}{*}{\begin{tabular}{c} 
Item \\
\cline { 2 - 8 }
\end{tabular}} & $\mathbf{R}_{\text {hitung }}$ & $\mathbf{R}_{\text {tabel }}$ & Keterangan & Tingkat validitas & Rhitung & $\mathbf{R}_{\text {tabel }}$ & Keterangan & Tingkat reliabilitas \\
\hline 1 & 0,474 & 0,235 & Valid & Sedang & 0,635 & 0,235 & Reliabel & Tinggi \\
2 & 0,348 & 0,235 & Valid & Rendah & 0,668 & 0,235 & Reliabel & Tinggi \\
3 & 0,312 & 0,235 & Valid & Rendah & 0,678 & 0,235 & Reliabel & Tinggi \\
4 & 0,347 & 0,235 & Valid & Rendah & 0,666 & 0,235 & Reliabel & Tinggi \\
5 & 0,334 & 0,235 & Valid & Rendah & 0,669 & 0,235 & Reliabel & Tinggi \\
6 & 0,375 & 0,235 & Valid & Rendah & 0,659 & 0,235 & Reliabel & Tinggi \\
7 & 0,423 & 0,235 & Valid & Sedang & 0,647 & 0,235 & Reliabel & Tinggi \\
8 & 0,439 & 0,235 & Valid & Sedang & 0,644 & 0,235 & Reliabel & Tinggi \\
\hline
\end{tabular}

Sumber: Data primer yang diolah, 2020 
Berdasarkan hasil perhitungan dengan menggunakan analisis statistik SPSS 21 diperoleh bahwa setiap item kuesioner motivasi kerja dinyatakan valid. Untuk aspek reliabilitas item diperoleh bahwa semua item pernyataan pada kuesioner sudah reliabel, dengan kriteria tingkat reliabilitas item "tinggi". Adapun kriteria tingkat validitas item kuesioner motivasi kerja didapatkan bahwa sebagian besar item kuesioner memiliki tingkat validitas rendah

Tabel 5. Nilai Validitas Dan Reliabilitas Kuesioner Kinerja

\begin{tabular}{ccccccccc}
\hline No. & \multicolumn{3}{c}{ Validitas } & & \multicolumn{3}{c}{ Reliabilitas } \\
\cline { 2 - 8 } Item & $\mathbf{R}_{\text {hitung }}$ & $\mathbf{R}_{\text {tabel }}$ & Keterangan & Tingkat validitas & $\mathbf{R}_{\text {hitung }}$ & $\mathbf{R}_{\text {tabel }}$ & Keterangan & Tingkat reliabilitas \\
\hline 1 & 0,698 & 0,235 & Valid & Tinggi & 0,931 & 0,235 & Reliabel & Sangat Tinggi \\
2 & 0,701 & 0,235 & Valid & Tinggi & 0,931 & 0,235 & Reliabel & Sangat Tinggi \\
3 & 0,576 & 0,235 & Valid & Sedang & 0,934 & 0,235 & Reliabel & Sangat Tinggi \\
4 & 0,754 & 0,235 & Valid & Tinggi & 0,929 & 0,235 & Reliabel & Sangat Tinggi \\
5 & 0,647 & 0,235 & Valid & Tinggi & 0,932 & 0,235 & Reliabel & Sangat Tinggi \\
6 & 0,607 & 0,235 & Valid & Tinggi & 0,933 & 0,235 & Reliabel & Sangat Tinggi \\
7 & 0,647 & 0,235 & Valid & Tinggi & 0,932 & 0,235 & Reliabel & Sangat Tinggi \\
8 & 0,738 & 0,235 & Valid & Tinggi & 0,930 & 0,235 & Reliabel & Sangat Tinggi \\
9 & 0,654 & 0,235 & Valid & Tinggi & 0,932 & 0,235 & Reliabel & Sangat Tinggi \\
10 & 0,759 & 0,235 & Valid & Tinggi & 0,930 & 0,235 & Reliabel & Sangat Tinggi \\
11 & 0,736 & 0,235 & Valid & Tinggi & 0,930 & 0,235 & Reliabel & Sangat Tinggi \\
12 & 0,592 & 0,235 & Valid & Sedang & 0,933 & 0,235 & Reliabel & Sangat Tinggi \\
13 & 0,708 & 0,235 & Valid & Tinggi & 0,931 & 0,235 & Reliabel & Sangat Tinggi \\
14 & 0,716 & 0,235 & Valid & Tinggi & 0,930 & 0,235 & Reliabel & Sangat Tinggi \\
15 & 0,708 & 0,235 & Valid & Tinggi & 0,931 & 0,235 & Reliabel & Sangat Tinggi \\
\hline
\end{tabular}

Sumber: Data primer yang diolah, 2020

Berdasarkan hasil perhitungan dengan menggunakan analisis statistik SPSS 21 diperoleh bahwa setiap item kuesioner kinerja dinyatakan valid. Untuk aspek reliabilitas item diperoleh bahwa semua item pernyataan pada kuesioner sudah reliabel, dengan kriteria tingkat reliabilitas item sangat tinggi. Adapun kriteria tingkat validitas item kuesioner kinerja didapatkan bahwa sebagian besar item kuesioner memiliki tingkat validitas tinggi.

\section{Kepemimpinan Transformasional, Budaya Organisasi, Motivasi, dan Kinerja Pegawai}

Berdasarkan hasil pengukuran penerapan budaya organisasi di Pengadilan Negeri Jambi, diketahui bahwa secara keseluruhan kualitas penerapan budaya organisasi di instansi tersebut sudah baik. Hal ini dibuktikan dari total perolahan skor hasil pengisian kuesioner oleh responden yaitu sebesar 3.093, dimana skor ini berada pada rentang skala 2.767,6 - 3.417,8 dengan kriteria baik. Dari kelima dimensi budaya organisasi, yaitu; inisiatif individu, dukungan manajemen, kontrol, pola komunikasi, dan toleransi terhadap tindakan berisiko, diketahui bahwa dimensi dukungan manajemen mendapatkan skor perolehan tertinggi dibandingkan empat dimensi lainnya. Berdasarkan hasil pengukuran motivasi kerja pegawai Pengadilan Negeri Jambi, diketahui bahwa secara keseluruhan motivasi kerja pegawai berada pada tingkat kualitasnya tinggi. Hal ini dibuktikan dari total perolahan skor hasil pengisian kuesioner oleh responden yaitu sebesar 2.091, dimana skor ini berada pada rentang skala 2.012,8 - 2.485,4 dengan kriteria tinggi. Dari ketiga dimensi motivasi kerja, yaitu; kebutuhan berprestasi, kebutuhan berafiliasi, dan kebutuhan kekuasaan, diketahui bahwa dimensi kebutuhan berafiliasi mendapatkan skor perolehan tertinggi dibandingkan dua dimensi lainnya. Hal ini dibuktikan dari total perolahan skor hasil pengisian kuesioner oleh responden, untuk variabel kinerja, yaitu sebesar 4.207, dimana skor ini berada pada rentang skala 3.774 - 4.661 dengan kriteria tinggi. Dari kelima dimensi kinerja pegawai, yaitu; kemampuan, efektivitas dan efisiensi, otoritas, disiplin, dan inisiatif, diketahui bahwa dimensi efektifitas dan efisiensi serta dimensi inisiatif mendapatkan skor perolehan tertinggi dibandingkan tiga dimensi lainnya. Terlepas dari peran kepemimpinan transformasional, budaya organisasi, dan motivasi kerja, dalam mempengaruhi kinerja pegawai, terdapat faktor lainnya yang juga dapat mempengaruhi tingginya kinerja pegawai, seperti yang diungkapkan oleh (Kasmir, 2016) yaitu: (1) kemampuan dan keahlian, merupakan kemampuan atau skill yang dimiliki seseorang dalam melakukan suatu pekerjaan. Semakin memiliki kemampuan dan keahlian, maka akan dapat menyelesaikan pekerjaannya secara benar, sesuai dengan yang telah ditetapkan, (2) pengetahuan, seseorang yang memiliki pengetahuan tentang pekerjaan secara baik akan memberikan hasil kerja yang baik, demikian pula sebaliknya, (3) rancangan kerja, merupakan rancangan pekerjaan yang akan memudahkan pegawai dalam mencapai tujuannya, dan (4) kepribadian, yang berkaitan dengan konsep diri atau karakter yang dimiliki seorang pegawai. 


\section{Pengaruh Kepemimpinan Transformasional terhadap Motivasi Kerja}

Hasil pengujian hipotesis dalam penelitian ini menunjukkan bahwa gaya kepemimpinan transformasional berpengaruh terhadap motivasi kerja pegawai Pengadilan Negeri Jambi. Hal ini dibuktikan dari hasil perolehan nilai t statistik sebesar 5,357, dimana nilai ini lebih besar dari nilai $t_{\text {tabel }}(1,990)$, dengan nilai probabilitas ( $p$-value) sebesar 0,000 $(<0,05)$. Dengan demikian didapatkan keputusan untuk menerima hipotesis, yaitu kepemimpinan transformasional secara parsial berpengaruh signifikan terhadap motivasi kerja pegawai Pengadilan Negeri Jambi. Berpengaruhnya gaya kepemimpinan transformasional terhadap motivasi kerja pegawai dikarenakan sebagian besar responden (pegawai) yakin bahwa pimpinan dapat dibanggakan, dapat dipercaya, memiliki rasa hormat, memberikan contoh agar karyawan loyal pada organisasi, mampu memotivasi karyawan untuk terus meningkatkan hasil kerjanya, layak sebagai figur yang patut diteladani, mendorong karyawan untuk lebih kreatif, menyampaikan idei-ide kepada karyawan dalam menyelesaikan pekerjaan, memiliki perhatian yang baik terhadap karyawan dan memberikan penghargaan secara langsung kepada karyawan yang berprestasi. Hal ini terbukti dari tanggapan mayoritas responden dalam penelitian ini, bahwa gaya kepemimpinan transformasional yang diterapkan di Pengadilan Negeri Jambi sudah baik, dengan rata-rata perolehan skor untuk gaya kepemimpinan transformasional yaitu 2.516 - 3.107. Selain itu, adanya pemberian dukungan dari pemimpin yang transformasional, seperti pemberian motivasi inspirasional, yang diwujudkan dalam bentuk menciptakan suatu lingkungan kerja yang membantu mempertebal keinginan pada setiap pengikut untuk melaksanakan pekerjaan sebaik mungkin dengan standar kerja yang tinggi, bekerjasama dengan pihak lain, serta mengembangkan skillnya dan keinginannya sendiri ternyata mampu membangkitkan semangat kerja pengikutnya. Hasil penelitian (Roy Johan Agung, Wayan Gede, I Gede, 2014) yang membuktikan bahwa bahwa gaya kepemimpinan transformasional berpengaruh positif dan signifikan terhadap motivasi kerja pegawai. Hal ini berarti semakin baik penerapan kepemimpinan transformasional maka akan semakin tinggi pula motivasi kerja pegawai.

\section{Pengaruh Budaya Organisasi terhadap Motivasi Kerja}

Hasil pengujian hipotesis dalam penelitian ini menunjukkan bahwa budaya organisasi berpengaruh terhadap motivasi kerja pegawai Pengadilan Negeri Jambi. Hal ini dibuktikan dari hasil perolehan nilai $\mathrm{t}$ statistik sebesar 2,020, dimana nilai ini lebih besar dari nilai $\mathrm{t}_{\text {tabel }}(1,990)$, dengan nilai probabilitas ( $p$-value) sebesar 0,047 $(<0,05)$. Dengan demikian didapatkan keputusan untuk menerima hipotesis, yaitu budaya organisasi secara parsial berpengaruh signifikan terhadap motivasi kerja pegawai Pengadilan Negeri Jambi. Penelitian(Sinha,Smrita., Ajay Kr, Nisha, Rajul \& S, Gupta, Dutt, 2010) yang menyimpulkan bahwa budaya organisasi berpengaruh positif dan signifikan terhadap motivasi kerja karyawan, dimana semakin kondusif antara atasan dan bawahan, karyawan dengan sesama karyawan serta dukungan lingkungan manajemen perusahaan maka semakin meningkatkan rasa nyaman dalam lingkungan organisasi, sehingga dapat mendorong motivasi kerja karyawan.

\section{Pengaruh Kepemimpinan Transformasional dan Budaya Organisasi terhadap Motivasi Kerja}

Hasil pengujian hipotesis dalam penelitian ini menunjukkan bahwa kepemimpinan transformasional dan budaya organisasi secara bersama-sama berpengaruh terhadap motivasi kerja pegawai Pengadilan Negeri Jambi. Hal ini dibuktikan dari hasil perolehan nilai $\mathrm{F}$ statistik sebesar 18,256 (Tabel 4.18), dimana nilai ini lebih besar dari nilai $F_{\text {tabel }}(2,74)$, dengan nilai probabilitas ( $p$-value) sebesar 0,000 $(<0,05)$. Dengan demikian didapatkan keputusan untuk menerima hipotesis, yaitu kepemimpinan transformasional dan budaya organisasi secara simultan berpengaruh signifikan terhadap motivasi kerja pegawai Pengadilan Negeri Jambi. Dengan demikian dapat dinyatakan bahwa terdapat interaksi antara kepemimpinan transformasional dan budaya organisasi, dimana semakin baik kepemimpinan transformasional dan budaya yang diterapkan di suatu organisasi, maka semakin tinggi pula motivasi kerja pegawai dalam mewujudkan tujuan organisasi tersebut. Penelitian dari (Sokro, 2012) menunjukkan adanya hubungan yang signifikan antara budaya organisasi dan motivasi kerja karyawannya. Budaya kerja yang kuat dapat menciptakan motivasi dan meningkatkan pada kinerja karyawan.

\section{Pengaruh Kepemimpinan Transformasional terhadap Kinerja Pegawai}

Hasil pengujian hipotesis dalam penelitian ini menunjukkan bahwa kepemimpinan transformasional berpengaruh terhadap kinerja pegawai Pengadilan Negeri Jambi. Hal ini dibuktikan dari hasil perolehan nilai t statistik sebesar 3,298 (Tabel 4.19), dimana nilai ini lebih besar dari nilai $t_{\text {tabel }}(1,990)$, dengan nilai probabilitas ( $p$-value) sebesar 0,002 $(<0,05)$. Dengan demikian didapatkan keputusan untuk menerima hipotesis, yaitu kepemimpinan transformasional secara parsial berpengaruh signifikan terhadap kinerja pegawai Pengadilan Negeri Jambi. Berpengaruhnya gaya kepemimpinan transformasional terhadap kinerja dikarenakan adanya atribut/unsur dalam kepemimpinan yang kuat, sebagaimana yang dikemukakan oleh (Bass, 1985) yang menjelaskan proses pengaruh sosial, dimana 
pemimpin memberikan atribut adanya kualitas positif yang kuat, seperti kemampuan untuk mengungkapkan visi dan nilai-nilai, kemudian para pengukut menginternalisasikann nilai-nilai dan keyakinankeyakinan para pemimpin dan berperilaku secara konsisten dengan karakteristik tersebut, termasuk menempatkan kepentingan kolektif diatas kepentingan diri sendiri.

\section{Pengaruh Budaya Organisasi terhadap Kinerja}

Hasil pengujian hipotesis dalam penelitian ini menunjukkan bahwa budaya organisasi berpengaruh terhadap kinerja pegawai Pengadilan Negeri Jambi. Hal ini dibuktikan dari hasil perolehan nilai t statistik sebesar 17,444 (Tabel 4.20), dimana nilai ini lebih besar dari nilai $\mathrm{t}_{\text {tabel }}(1,990)$, dengan nilai probabilitas ( $p$-value) sebesar 0,000 $(<0,05)$. Dengan demikian didapatkan keputusan untuk menerima hipotesis, yaitu budaya organisasi secara parsial berpengaruh signifikan terhadap kinerja pegawai Pengadilan Negeri Jambi. Hasil penelitian (Sari, 2013) dalam penelitiannya menyatakan bahwa pengaruh budaya organisasi bisa menciptakan situasi yang dapat mendorong karyawan agar meningkatkan kinerja yang mereka miliki. Karena dengan adanya suatu budaya organisasi yang baik dan terarah dapat menjalankan pekerjaan dengan runtun dengan hasil yang maksimal.

\section{Pengaruh Motivasi Kerja Terhadap Kinerja Pegawai}

Hasil pengujian hipotesis dalam penelitian ini diketahui bahwa motivasi kerja berpengaruh tidak signifikan terhadap kinerja pegawai. Hal ini dibuktikan dari hasil perolehan nilai $t$ statistik sebesar 1,518 (Tabel 4.21), dimana nilai ini lebih kecil dari nilai tabel $(1,990)$, dengan nilai probabilitas ( $p$-value) sebesar 0,134 (> $0,05)$. Dengan demikian didapatkan keputusan untuk menolak hipotesis, yang berarti motivasi kerja secara parsial berpengaruh tidak signifikan terhadap kinerja pegawai Pengadilan Negeri Jambi. Hasil pengujian ini menunjukkan masih adanya gap (kesenjangan) dengan hasil temuan terdahulu dan teori, sebagaimana yang telah dijelaskan sebelumnya. Dengan demikian dapat dinyatakan bahwa setinggi apa pun motivasi kerja pegawai Pengadilan Negeri Jambi, tidak memberikan kontribusi yang berarti bagi peningkatan kinerja pegawai di lembaga hukum tersebut. Tidak berpengaruhnya motivasi kerja terhadap kinerja pegawai Pengadilan Negeri Jambi, dapat disebabkan oleh faktor lain yang diduga memperlemah hubungan antara motivasi kerja dengan kinerja, atau dapat dikatakan adanya variabel moderator yang tidak diteliti dalam penelitian ini, namun diduga memperlemah hubungan diantara kedua variabel. Adapun faktor yang diduga sebagai moderator dalam penelitian ini adalah karakteristik responden dalam penelitian ini, seperti; usia, jenis kelamin, pendidikan, dan masa kerja, dimana karakteristik ini juga dapat mempengaruhi tinggi rendahnya kinerja individu.Terkait hubungan masa kerja dengan kinerja, (Muttaqin, Made, Lulup, 2014) mengemukakan bahwa masa kerja karyawan juga berpengaruh terhadap kinerjanya. Hal senada juga dinyatakan oleh (Risma, 2012) bahwa masa kerja (pengalaman) merupakan salah satu faktor yang berpengaruh terhadap kinerja pegawai.

\section{Pengaruh Kepemimpinan Transformasional dan Budaya Organisasi terhadap Kinerja melalui Motivasi Kerja}

Berdasarkan pemaparan hubungan antara kepemimpinan transformasional, budaya organisasi, motivasi kerja, dan kinerja, menunjukkan bahwa motivasi kerja merupakan akibat dari baiknya kualitas penerapan kepemimpinan transformasional dan budaya organisasi di Pengadilan Negeri Jambi, sekaligus sebagai sebab dari tingginya kinerja pegawai di instansi tersebut. Hal ini terbukti dari hasil pengujian hipotesis melalui uji sobel didapatkan nilai t statistik sebesar 19,494, dimana nilai ini lebih besar dari nilai $t_{\text {tabel }}(1,990)$. Dengan demikian didapatkan keputusan untuk menerima hipotesis, yaitu kepemimpinan transformasional dan budaya organisasi secara tidak langsung berpengaruh signifikan terhadap kinerja pegawai Pengadilan Negeri Jambi melalui motivasi kerja. Atau dengan kata lain, motivasi kerja dapat memediasi pengaruh tidak langsung antara kepemimpinan transformasional dan budaya organisasi terhadap kinerja pegawai. Hasil pengujian ini menerangkan bahwa bukti empiris yang ditemukan dalam penelitian ini sejalan dengan hasil temuan terdahulu, seperti penelitian;(Aditia \& Yuniawan, 2015), yang menunjukkan bahwa motivasi kerja dapat memediasi pengaruh tidak langsung antara kepemimpinan transformasional dan budaya organisasi terhadap kinerja pegawai.

\section{SIMPULAN}

Berdasarkan hasil penelitian yang telah didapatkan, maka dapat disimpulkan sebagai berikut:

Gambaran tingkat kualitas kepemimpinan transformasional dan budaya organisasi di Pengadilan Negeri Jambi secara keseluruhan berada pada tingkat kualitas yang baik. Sementara untuk motivasi kerja dan kinerja pegawai Pengadilan Negeri Jambi secara keseluruhan berada pada tingkat kualitas yang tinggi. Hal ini dibuktikan dari hasil perolehan skor, yaitu; (1) kepemimpinan transformasional memperoleh skor 2.672 dari rentang skala 2.516-3.107 dengan kriteria "baik", (2) budaya organisasi memperoleh skor 3.093 dari rentang skala 2.767,6 -3.417,8 dengan kriteria "baik", (3) motivasi kerja memperoleh skor 2.091 dari rentang skala $2.012,8$ - 2.485,4 dengan kriteria "tinggi", dan (4) kinerja memperoleh skor 4.207 dari rentang skala 3.774 - 4.661 dengan kriteria "tinggi". Faktor yang berpengaruh terhadap kinerja pegawai Pengadilan 
Negeri Jambi tidak hanya dibatasi pada variabel kepemimpinan transformasional, budaya organisasi, dan motivasi kerja. Oleh karena itu, bagi penelitian mendatang agar mengembangkan penelitian ini dengan melibatkan variabel lainnya di instansi yang sama, sehingga akan menambah referensi yang lebih banyak dalam upaya pencapaian target kinerja dan memberikan pelayanan yang baik kepada masyarakat.

\section{DAFTAR PUSTAKA}

Aditia, Y. C., \& Yuniawan, A. (2015). Pengaruh Gaya Kepemimpinan Transformasional dan Budaya Organisasi terhadap Kinerja Karyawan: Motivasi Kerja sebagai Variabel Intervening (Studi pada Karyawan Kantor Pusat PT Nindya Karya). Diponegoro Journal of Management, 4(3), 1-12.

Bass, B. M. (1985). Leadership and Performance Beyond Expectations.

Hadian,Adang, D. (2014). Perilaku Keorganisasian. STIE Pasundan Press dan CV Warta Bagja.

Kasmir. (2016). Manajemen Sumber Daya Manusia (Teori dan Praktik). Cetakan ke-1. PT. Raja Grafindo Persada.

Malayu, S. P. (2007). Manajemen Sumber Daya Manusia. Cetakan Kesembilan. PT Bumi Aksara.

Mangkunegara, A.P. (2009). Manajemen Sumber Daya Manusia Perusahaan. Rosda:Bandung.

Muttaqin, Made, Lulup, A., N, E. T. (2014). Pengaruh Latar Belakang Pendidikan, Masa Kerja Dan Motivasi Kerja Terhadap Kinerja Karyawan Pada PT. Indocitra Jaya Samudra Negara-Bali Tahun 2013. Jurnal Pendidikan Ekonomi, Vol. 4 (1).

Priadana, Hadian, M. S., D. (2011). Paradigma Kepemimpinan Indonesia. STIE Pasundan Press dan LoGoZ Publishing.

Risma, D. (2012). Pengaruh Kecerdasan Emosional Terhadap Kinerja Karyawan. Jurnal Educhild, Vol. 1 (1).

Robbin, Stephen, Judge, Timothy, A. (2015). Perilaku Organisasi. Salemba Empat.

Robbins, Judge, S. P., T. A. (2008). Organisational Behaviour (13th edition). Prentice Hall.

Roy Johan Agung, Wayan Gede, I Gede, R. J. A. T., Wayan Gede Supartha, dan I. Gede Riana, \& Tacunan, Supartha, Riana. (2014). Pengaruh Kepemimpinan Transformasional terhadap Motivasi dan Kinerja Karyawan (Sudi Kasus Pada PT. Pandawa). E-Jurnal Ekonomi Dan Bisnis Universitas Udayana, Vol. 3 (9):533-550.

Sari, E. V. (2013). Pengaruh Budaya Organisasi Terhadap Kinerja Karyawan Pada PT. Taspen (Persero) Cabang Yogyakarta. Naskah Publikasi, Fakultas Ekonomi, Universitas Negeri Yogyakarta.

Sedarmayanti. (2010). Sumber daya Manusia dan Produktifitas Kerja.
Siagian, S. P. (2011). Manajemen Sumber Daya Manusia.

Sinha,Smrita., Ajay Kr, Nisha, Rajul, \& S, Gupta, Dutt. (2010). Impact of Work Culture on Motivation and Performance Level of Employees in Private Sector Companies. Acta Oeconomica Pragensia, Vol. 18(6): 49-67.

Soedjono. (2005). Pengaruh Budaya Organisasi Terhadap Kinerja Organisasi dan Kepuasan Kerja Karyawan Pada Terminal Penumpang Umum di Surabaya. Jurnal Fakultas Ekonomi - Universitas Kristen Petra.

Sokro, E. (2012). Analysis of The Relationship that Exist Between Organisational Culture, Motivation and Performance. Problems of Management in the 21st Century, Vol. 3, pp.106-119.

Suranta, S. (2005). Dampak Motivasi Karyawan Pada Hubungan Antara Gaya KepemimpinanDengan Kinerja Karyawan Perusahaan Bisnis. Empirika.

Syekh, S. (2011). Pengantar Statistik Ekonomi dan Sosial. Gaung Persada.

Tjiptono, F. (2006). Manajemen Pelayanan Jasa. Penerbit Andi.

Yukl, G. (2010). Leadership in Organization. Alih Bahasa oleh Udaya Jusuf: Kepemimpinan dalam Organisasi. 